\title{
PENGARUH NPL, LDR, DAN ROA TERHADAP PENYALURAN KREDIT PADA BANK UMUM KONVENSIONAL YANG TERDAFTAR DI BURSA EFEK INDONESIA PERIODE 2018-2020
}

\author{
Eveline Ester Saumur $^{1}$, Sri Wellis Anggraeni ${ }^{2}$ dan Nana Diana ${ }^{3}$ \\ ${ }_{1,2,3}$ Akuntansi \\ Fakultas Ekonomi \\ Universitas Singaperbangsa Karawang \\ Email : 1810631030002@student.unsika.ac.id ${ }^{1}$,1810631030042@student.unsika.ac.id², \\ nana.diana@fe.unsika.ac.id ${ }^{3}$
}

\begin{abstract}
ABSTRAK
Penyaluran kredit merupakan salah satu fungsi dari bank yang digunakan bagi peningkatan kegiatan ekonomi masyarakat. Proses penyaluran kredit ini akan mempertimbangkan faktor tertentu seperti Non-Performing Loan (NPL), Loan to Deposit Ratio (LDR), dan Return on Asset (ROA). Penelitian ini menguji dampak variabel NPL, LDR dan ROA ke penyaluran kredit terutama pada bank umum konvesional periode 20182020. Metode penelitian menggunakan deskriptif verifikatif berdasarkan pendekatan kuantitatif dan dianalisis menggunakan regresi linier berganda. Data penelitian berupa laporan historis rasio keuangan dan laporan tahunan. Populasi sebanyak 41 bank dan yang menjadi sampel penelitian sebesar 24 bank. Penelitian menghasilkan terdapat pengaruh NPL, LDR dan ROA baik secara parsial maupun simultan terhadap penyaluran kredit pada bank umum konvensional periode 2018-2020.
\end{abstract}

Kata Kunci: NPL, LDR, ROA, penyaluran kredit

\begin{abstract}
Credit distribution is one of the tasks of banks to increase community economic activities. The credit distribution process will consider certain factors such as NonPerforming Loan (NPL), Loan to Deposit Ratio (LDR), and Return on Assets (ROA). This study examines the impact of the NPL, LDR and ROA variables on lending, especially in conventional commercial banks for the 2018-2020 period. The research method uses descriptive verification based on a quantitative approach and is analyzed using multiple linear regression. The research data are in the form of historical financial ratio reports and annual reports. The population is 41 banks and the research sample is 24 banks. The research shows that there is an effect of NPL, LDR and ROA either partially or simultaneously on lending to Conventional Commercial Banks for the 2018-2020 period.
\end{abstract}

Keywords: NPL, LDR, ROA, credit distribution 


\section{PENDAHULUAN}

Lembaga keuangan yang mempunyai peran besar guna meningkatkan perekonomian negara yang secara umum sudah diketahui oleh masyarakat luas yaitu perbankan. Bank dapat dikatakan sebagai lembaga keuangan yang dapat digunakan oleh masyarakat untuk kegiatan peminjaman uang (kredit) sesuai dengan salah satu tugas bank yaitu perantara keuangan bagi kedua belah pihak yaitu yang memerlukan modal dengan yang mempunyai modal. Adapun prinsip dan kegiatan bank umum dilakukan secara konvensional. Pertumbuhan bank umum konvensional terbilang cukup pesat dan dominan daripada bank umum syariah sehingga bank umum konvensional akan menjadi obyek penelitian. Di lihat dari tiga tahun terakhir, meskipun secara kuantitatif jumlah bank umum konvensional menurun, walaupun demikian produk yang ditawarkan bank umum konvensional yaitu tabungan, giro, deposito dan penyaluran kredit mengalami pertumbuhan.

Penyaluran kredit disebut juga sebagai aktivitas utama bank yang dapat menciptakan dan meningkatkan laba, akan tetapi penyaluran kredit juga memiliki tingkat risiko yang tinggi. Dengan penyaluran kredit ini masyarakat dapat terpengaruh oleh bank untuk melakukan aktivitas kewirausahaan, sehingga pendapatan masyarakat dapat meningkat dan dengan secara tidak langsung membuat berkurangnya tingkat pengangguran yang mana nantinya akan berpengaruh juga pada meningkatnya perekonomian negara. Dalam memberikan kredit terdapat faktor-faktor yang perlu dipertimbangkan oleh bank guna menentukan besarnya kredit yang akan dialokasikan, seperti NPL, LDR, dan ROA.

Dalam dunia perbankan Non-Performing Loan (NPL) indikator yang berfungsi untuk melihat kesehatan aset pada suatu bank. Cara untuk mengetahui nilai NPL, yaitu menghitung pembiayaan non lancar terhadap total pembiayaan. Menurut Ali dalam Handayani (2018) menjelaskan rasio NPL sebagai cerminan risiko kredit, dengan meningginya tingkat rasio NPL bank akan semakin besar dalam menanggung risiko kreditnya.

Loan to Deposit Ratio (LDR) berfungsi menilai komposisi jumlah kredit yang dialokasikan dibandingkan dengan jumlah dana masyarakat dan ekuitas 
sendiri yang dipergunakan. Tingginya LDR membuat tingkat likuiditas semakin tinggi, apabila rasio LDR melebihi $100 \%$ yang artinya kurang baiknya tingkat likuiditas suatu bank. Dengan batas wajar 80\% - 100\% memperlihatkan rasio LDR yang baik dan kondisi likuiditas bank juga sehat.

Return on Asset (ROA) berfungsi memperkirakan efisien dan efektifitas suatu entitas untuk memperoleh profit, selain itu juga merupakan indikator yang akan menggambarkan jika rasio ini mengalami peningkatan maka dapat dikatakan bahwa sudah optimalnya penggunaan aset suatu bank dalam memperoleh keuntungan. Dalam perbankan tentunya terdapat resiko kegagalan. Salah satu resikonya yakni macetnya pelunasan oleh debitur yang memicu kredit bermasalah sehingga berimbas pada bank ketika mendistribusikan kreditnya. Hal ini sangat krusial dari sisi bank agar memeriksa bahkan mengobservasi sedari awal apakah debitur sanggup membayar kembali pinjaman atau tidak.

Adapun temuan dari peneliti-peneliti terdahulu yang melatarbelakangi penelitian ini dengan variabel serupa namun dengan hasil berbeda. Setyawan (2016) menemukan kredit tidak dipengaruhi signifikan oleh NPL dan ROA. Namun, Molek dan Akmalia (2016) menemukan penyaluran kredit secara signifikan dipengaruhi positif oleh ROA tetapi NPL ternyata mempengaruhi negatif signifikan sedangkan penyaluran kredit tidak dipengaruhi secara signifikan oleh LDR. Menurut Fitria, et al (2017) menjelaskan bahwa pemberian kredit dipengaruhi oleh LDR secara negatif signifikan tetapi NPL sama sekali tidak berpengaruh secara signifikan ke pemberian kredit. Sehingga, penelitian ini memiliki tujuan guna menguji pengaruh NPL, LDR dan ROA terhadap penyaluran kredit pada bank umum konvensional yang terdaftar di Bursa Efek Indonesia periode 2018-2020.

\section{METODE PENELITIAN}

Metode deskriptif verifikatif dengan pendekatan kuantitatif merupakan metode yang digunakan dalam penelitian ini. Lingkup objek penelitian yang ditetapkan adalah Bank Umum Konvensional yang terdaftar di Bursa Efek Indonesia periode 2018-2020. 
Tabel 1. Definisi Operasional Variabel Penelitian

\begin{tabular}{|c|l|l|l|}
\hline Variabel & \multicolumn{1}{|c|}{ Keterangan } & Indikator & Skala \\
\hline $\begin{array}{c}\text { Penyaluran } \\
\text { Kredit }\end{array}$ & $\begin{array}{l}\text { Jumlah Kredit yang } \\
\text { disalurkan oleh Bank }\end{array}$ & $\begin{array}{l}\text { Jumlah kredit bank umum pada } \\
\text { akhir periode tahunan. }\end{array}$ & Rasio \\
\hline NPL & $\begin{array}{l}\text { Besarnya kredit bermasalah } \\
\text { yang digolongkan ke dalam } \\
\text { kredit yang kolektibilitasnya } \\
\text { kurang lancar, diragukan, } \\
\text { dan macet terhadap kredit } \\
\text { yang dikeluarkan. }\end{array}$ & NPL $=\frac{\text { Kredit Bermasalah }}{\text { Total } \text { Kredit }} \times 100 \%$ & Rasio \\
\hline LDR & $\begin{array}{l}\text { Mengukur komposisi jumlah } \\
\text { kredit yang diberikan } \\
\text { dibandingkan dengan jumlah } \\
\text { dana masyarakat dan modal } \\
\text { sendiri yang digunakan }\end{array}$ & LDR $=\frac{\text { Total } \text { Kredit }}{\text { Dana Pihak } \text { Ketiga }} \times 100 \%$ & Rasio \\
\hline ROA & $\begin{array}{l}\text { Perbandingan laba bersih } \\
\text { sebelum pajak terhadap total } \\
\text { aktiva }\end{array}$ & ROA $=\frac{\text { Laba Sebelum } \text { Pajak }}{\text { Total } \text { Aset }}$ & Rasio \\
\hline
\end{tabular}

Sumber: Kajian Peneliti, 2021

Jenis data yaitu data sekunder berupa laporan historis rasio-rasio keuangan bersumber dari website resmi bank dan laporan tahunan bank umum konvensional yang terdaftar di BEI dari tahun 2018 hingga 2020. Metode yang dipakai yakni studi pustaka dan dokumentasi. Analisis yang diaplikasikan ialah analisis regresi linear berganda. Bank umum konvensional yang tercatat pada BEI sebanyak 41 bank. Sementara itu, sampel penelitian sebanyak 24 bank menggunakan teknik purposive sampling. 
Tabel 2. Kriteria Pemilihan Sampel dengan Teknik Purposive Sampling

\begin{tabular}{|c|l|c|}
\hline No & \multicolumn{1}{|c|}{ Keterangan } & Jumlah \\
\hline 1 & Bank Umum Konvensional yang terdaftar di Bursa Efek Indonesia & 41 \\
\hline 2 & $\begin{array}{l}\text { Bank Umum Konvensional yang sudah menerbitkan serta } \\
\text { mempublikasikan laporan keuangannya di BEI secara berturut-turut } \\
\text { selama tahun 2018-2020 }\end{array}$ & $(5)$ \\
\hline 3 & $\begin{array}{l}\text { Bank Umum Konvensional yang laporan keuangannya selalu } \\
\text { mendapatkan laba secara berturut-turut selama periode penelitian }\end{array}$ & (11) \\
\hline 4 & $\begin{array}{l}\text { Bank Umum Konvensional yang menyediakan rasio serta data keuangan } \\
\text { yang diperlukan periode 2018-2020. }\end{array}$ & 24 \\
\hline \multicolumn{2}{|l}{ Jumlah Bank Umum Konvensional yang sesuai dengan kriteria sebagai sampel } \\
\hline
\end{tabular}

Sumber: Kajian Peneliti, 2021

\section{HASIL DAN PEMBAHASAN}

1. Analisis Statistik Deskriptif

Data tabel 3 menyatakan jumlah dari observasi data sebanyak 72 sampel. Pada NPL tercatat nilai minimum 0,80; nilai maksimum 7,83; standart deviasi 1,39384 dan rata-rata sebesar 2,9054. LDR berdasarkan analisis tercatat nilai minimum 41,26; nilai maksimum 163,00; standar deviasi sebesar 17,6244 dan rata-rata sebesar 85,4931. Variabel independen ROA tercatat dengan nilai minimum 0,10; nilai maksimum 4,00; standar deviasi 1,12251 dan rata-rata sebesar 1,6242. Penyaluran kredit tercatat nilai minimum 14,38; nilai maksimum 20,62; standar deviasi 1,76577 dan nilai rata- rata 17,7431.

Tabel 3. Deskriptif Statistik

\begin{tabular}{|l|r|r|r|r|r|}
\hline \multicolumn{7}{|c|}{ Descriptive Statistics } \\
\hline & $\mathrm{N}$ & \multicolumn{1}{|c|}{ Minimum } & \multicolumn{1}{c|}{ Maximum } & \multicolumn{1}{c|}{ Mean } & $\begin{array}{c}\text { Std. } \\
\text { Deviation }\end{array}$ \\
\hline NPL & 72 & .80 & 7.83 & 2.9054 & 1.39384 \\
\hline LDR & 72 & 41.26 & 163.00 & 85.4931 & 17.62244 \\
\hline ROA & 72 & .10 & 4.00 & 1.6242 & 1.12251 \\
\hline Penyaluran Kredit & 72 & 14.38 & 20.62 & 17.7431 & 1.76577 \\
\hline Valid N (listwise) & 72 & \multicolumn{7}{|l|}{} \\
\hline
\end{tabular}

Sumber: Data diolah SPSS, 2021 
2. Analisis Regresi Linier Berganda

Berdasarkan persamaan regresi memperlihatkan nilai konstanta 12,233 artinya NPL, LDR dan ROA dianggap nol dengan penyaluran kredit 12,233.

Penyaluran $\operatorname{kredit}(Y)=12,233+0,381 N P L\left(X_{1}\right)+0,032 L D R\left(X_{2}\right)+1,032 R O A\left(X_{3}\right)$ Nilai NPL yang positif sebesar 0,381 didapati adanya peningkatan NPL sebanyak 1, maka terjadi kenaikan sebesar 0,381 pada penyaluran kredit. Pada LDR tercatat positif 0,032 berarti adanya peningkatan, LDR sebesar 1, sehingga penyaluran kredit mengalami kenaikan 0,032. Sementara pada ROA yang positif 1,032 menunjukkan adanya kenaikan sebesar 1, berimbas kenaikan pada penyaluran kredit sebesar 1,032.

Tabel 4. Hasil Analisis Regresi Linier Berganda

\begin{tabular}{|c|c|c|c|c|c|c|}
\hline \multicolumn{7}{|c|}{ Coefficients $^{a}$} \\
\hline \multirow{2}{*}{\multicolumn{2}{|c|}{ Model }} & \multicolumn{2}{|c|}{$\begin{array}{l}\text { Unstandardized } \\
\text { Coefficients }\end{array}$} & \multirow{2}{*}{$\begin{array}{c}\begin{array}{c}\text { Standardized } \\
\text { Coefficients }\end{array} \\
\text { Beta } \\
\end{array}$} & \multirow[t]{2}{*}{$t$} & \multirow[t]{2}{*}{ Sig. } \\
\hline & & $\mathrm{B}$ & Std. Error & & & \\
\hline \multirow[t]{4}{*}{1} & (Constant) & 12.233 & 1.064 & & 11.494 & .000 \\
\hline & NPL & .381 & .143 & .300 & 2.668 & .010 \\
\hline & LDR & .032 & .009 & .319 & 3.389 & .001 \\
\hline & ROA & 1.032 & .176 & .656 & 5.864 & .000 \\
\hline
\end{tabular}

a. Dependent Variable: Penyaluran Kredit

Sumber: Data diolah SPSS, 2021

a. Pada uji t didapatkan bahwa signifikan NPL 0,010 dan t hitung 2,668. Ini berarti nilai signifikan $<0,005$ dan $\mathrm{t}$ hitung $>\mathrm{t}$ tabel $(1,99547)$ sehingga $\mathrm{H}_{0}$ ditolak maka $\mathrm{H}_{1}$ diterima. Artinya penyaluran kredit dipengaruhi oleh NPL.

b. Untuk variabel LDR, signifikan $0,001<0,005$. Lalu pada t hitung 3,389 >t tabel 1,99547. Berdasarkan hasil tersebut $\mathrm{H}_{0}$ ditolak maka $\mathrm{H}_{2}$ diterima sehingga penyaluran kredit dipengaruhi oleh LDR.

c. Uji statistik t untuk ROA signifikansi $0,000<0,05$ dan nilai thitung 5,864 > $\mathrm{t}$ tabel 1,99547. Maka hasil keputusan $\mathrm{H}_{0}$ ditolak, $\mathrm{H}_{3}$ diterima, dan penyaluran kredit dipengaruhi secara positif oleh ROA. 
Tabel 5. Koefisien Determinasi

\begin{tabular}{|c|r|r|r|r|r|}
\hline \multicolumn{7}{|c|}{ Model Summary $^{\mathbf{b}}$} \\
\hline \multirow{2}{*}{ Model } & $\mathrm{R}$ & $\mathrm{R}$ Square & $\begin{array}{c}\text { Adjusted } \\
\text { R Square }\end{array}$ & $\begin{array}{c}\text { Std. Error of the } \\
\text { Estimate }\end{array}$ & $\begin{array}{c}\text { Durbin- } \\
\text { Watson }\end{array}$ \\
\hline 1 & $.642^{\mathrm{a}}$ & .412 & .386 & 1.38386 & 1.258 \\
\hline
\end{tabular}

a. Predictors: (Constant), ROA, LDR, NPL

b. Dependent Variable: Penyaluran Kredit

Sumber: Data diolah SPSS, 2021

Pada tabel 5, Adjusted $R$ Square bernilai 0,386 menunjukkan kemampuan variabel bebas dalam mempengaruhi variabel terikat sebesar $38,6 \%$ dan $61,4 \%$ dipengaruhi oleh faktor lain di luar penelitian.

Tabel 6. Hasil Uji Statistik F

\begin{tabular}{|l|l|r|r|r|r|r|}
\hline \multicolumn{2}{|c|}{ ANOVA $^{\text {b }}$} \\
\hline \multicolumn{2}{|c|}{ Model } & $\begin{array}{c}\text { Sum of } \\
\text { Squares }\end{array}$ & df & $\begin{array}{c}\text { Mean } \\
\text { Square }\end{array}$ & F & Sig. \\
\hline \multirow{3}{*}{1} & Regression & 91.150 & 3 & 30.383 & 15.866 & $.000^{\mathrm{a}}$ \\
\cline { 2 - 8 } & Residual & 130.224 & 68 & 1.915 & & \\
\cline { 2 - 8 } & Total & 221.374 & 71 & & & \\
\hline
\end{tabular}

a. Predictors: (Constant), ROA, LDR, NPL

b. Dependent Variable: Penyaluran Kredit

Sumber: Data diolah SPSS, 2021

Melalui pengujian tabel 6 diperoleh F hitung 15,866> F tabel $(3 ; 69)$ yakni 0,365 dengan signifikansi (sig) $0,000<0,05$ oleh karena itu disimpulan $\mathrm{H}_{0}$ ditolak dan $\mathrm{H}_{4}$ diterima. Maka ditemukan NPL, LDR serta ROA secara bersama berpengaruh terhadap penyaluran kredit.

3. Pembahasan

a. Pengaruh NPL terhadap Penyaluran Kredit

Bank dinyatakan tidak mampu beroperasi jika batas NPL melebihi $5 \%$, dikarenakan tingginya rasio menyebabkan kualitas bank menjadi tidak baik. Tingginya NPL membuat bank harus mempersiapkan lebih banyak cadangan sehingga modal bank semakin menipis. Hasil penelitian menunjukkan NPL secara parsial ada pengaruh pada penyaluran kredit bank umum konvensional yang tercatat di BEI Periode 2018-2020. Kondisi ini bertentangan dengan penelitian Setyawan (2016) dan Fitria, Masyhad, \& Rosyafah (2017) yang menunjukkan NPL tidak berpengaruh signifikan atas penyaluran kredit. 
b. Pengaruh LDR terhadap Penyaluran Kredit

Hasil perhitungan nilai LDR diketahui banyak dibawah $80 \%$ dan juga lebih dari $92 \%$. Suatu bank terlihat sehat jika tingkat persentase LDR dengan rentang antara $80 \%$ sampai $92 \%$. Hasil penelitian menunjukkan LDR berpengaruh atas penyaluran kredit bank umum konvensional di BEI periode 2018-2020. LDR mampu mempengaruhi positif dan signifikan terhadap penyaluran kredit. Kondisi tersebut mencerminkan kebanyakan bank umum konvensional cukup efisien dan sebagian lainnya belum efisien dalam mengumpulkan sebanyak-banyaknya keuntungan dari dana yang dipinjamkan kepada masyarakat. Dalam penelitian Fitria, Masyhad \& Rosyafah (2017) menjelaskan pemberian kredit dipengaruhi signifikan negatif oleh LDR.

c. Pengaruh ROA terhadap Penyaluran Kredit

Hasil penelitian mencatat penyaluran kredit dipengaruhi oleh ROA secara parsial. Jika ROA semakin tinggi berakibat pada kredit yang dialokasikan juga semakin tinggi dan jika ROA semakin rendah maka kredit yang dialokasikan juga akan semakin rendah. Apabila bank mempunyai ROA yang rendah, maka semakin kecil tingkat labanya. Hasil penelitian ini selaras dengan penelitian Putri \& Akmalia (2016) yaitu ROA mempunyai pengaruh positif dan signifikan terhadap penyaluran kredit.

\section{KESIMPULAN DAN SARAN}

Kesimpulan berdasarkan hasil analisis yang telah dilakukan menyatakan bahwa penyaluran kredit dipengaruhi secara positif signifikan baik oleh NPL, LDR maupun ROA secara parsial. Sementara pengujian simultan menunjukkan bahwa penyaluran kredit dapat dipengaruhi secara signifikan oleh NPL, LDR dan ROA. Penelitian selanjutnya dapat memilih faktor lain yang belum diteliti dalam penelitian ini untuk dikaitkan pengaruhnya terhadap proses penyaluran kredit di dalam bank umum. 


\section{DAFTAR PUSTAKA}

Fitria, et al. (2107). Pengaruh DPK, CAR, NPL dan LDR Terhadap Jumlah Pemberian Kredit (Studi Pada Bank Umum Yang Terdaftar Di Bursa Efek Indonesia Tahun 2013-2015). E-Journal Akuntansi "EQUITY". Vol 3 (2)

Handayani, Asih. (2018). Pengaruh DPK, NPL dan ROA Terhadap Penyaluran Kredit Pada Bank Umum Yang Terdaftar Di Bursa Efek Indonesia Periode 2011-2014. Jurnal Penelitian Ekonomi dan Akuntansi. Vol 3 (1).

Kasmir. (2018). Bank Dan Lembaga Keuangan Lainnya Edisi revisi 2014. Jakarta: PT RajaGrafindo Persada.

Melinda, Venna. et. al. (2021). Pengaruh Dana Pihak Ketiga, Capital Adequacy Ratio, Non Performing Loan Dan Tingkat Suku Bunga terhadap Penyaluran Kredit Bank Umum Yang Terdaftar di Bursa Efek Indonesia. Jurnal Ilmiah Universitas Batanghari Jambi 21 (1), Februari 2021, 34-41

Molek, Y., \& Akmalia, A. (2016). Pengaruh CAR, NPL, ROA, dan LDR terhadap Penyaluran Kredit pada Perbankan (Studi pada Perusahaan yang Listed di Bursa Efek Indonesia Periode 2011-2015). Jurnal Balance, 8(2).

Rosalina, R., Enas., \& Lestari, M, N. (2019). Pengaruh Non Performing Loan (NPL) Terhadap Penyaluran Kredit. Business Management and Entrepreneurship Journal, Vol 1, No 4

Setyawan. (2016). Pengaruh DPK, CAR, NPL, ROA, SBI dan Pertumbuhan Ekonomi Terhadap Penyaluran Kredit Perbankan Pada Bank Umum Yang Terdaftar Di Bursa Efek Indonesia. Kurs: Jurnal Akuntansi, Kewirausahaan \& Bisnis. Vol 1 (1).

Sutrisno. 2018. Manajemen Keuangan Teori Konsep \& Aplikasi. Yogyakarta: EKONISIA 